\title{
Impact of prematurity for pancreatic islet and beta-cell development
}

\author{
Frank H Bloomfield \\ Liggins Institute, University of Auckland, Auckland, New Zealand \\ Correspondence should be addressed to F Bloomfield: f.bloomfield@auckland.ac.nz
}

\section{Abstract}

As increasing numbers of babies born preterm survive into adulthood, it is becoming

Key Words clear that, in addition to the well-described risks of neurodevelopmental sequelae, there also are increased risks for non-communicable diseases, including diabetes. Epidemiological studies indicate that risks are increased even for birth at late preterm and early term gestations and for both type 1 and type 2 diabetes. Thus, factors related to preterm birth likely affect development of the fetal and neonatal betacell in addition to effects on peripheral insulin sensitivity. These factors could operate prior to preterm birth and be related to the underlying cause of preterm birth, to the event of being born preterm itself, to the postnatal care of the preterm neonate or to a combination of these exposures. Experimental evidence indicates that factors may be operating during all these critical periods to contribute to altered development of beta-cell mass in those born preterm. Greater understanding of how these factors impact upon development of the pancreas may lead to interventions or management approaches that mitigate the increased risk of later diabetes.
$\checkmark$ fetus
- neonate
- nutrition
- metabolism
- diabetes

\section{Preterm birth and the later risk of diabetes}

Preterm birth (birth before 37 completed weeks' gestation) occurs in $11.1 \%$ of births globally, with most countries showing increasing rates over the past two decades (Blencowe et al. 2012). The neonatal mortality rate from preterm birth is decreasing, counterbalanced to some extent by the increasing preterm birth rates (Blencowe et al. 2013 c), most of which is due to increases in late preterm births (births at 35-36 weeks' gestation) (Davidoff et al. 2006). Although outcomes from moderate-late preterm birth (32-36 weeks' gestation) are excellent compared with those from very and extremely preterm birth (before 32 -weeks' gestation), because $>80 \%$ of preterm babies are born at moderate-to-late preterm gestations, the majority of the global life-long health burden following preterm birth is accounted for by these babies (Blencowe et al. $2013 b$ ). The focus in the early years of neonatal intensive care was on survival; as mortality rates have decreased, the focus has been on survival free of neurodisability. As increasing numbers of people born preterm reach middle and older adulthood, there is increasing awareness of the potential for those born preterm also to be at risk of non-communicable diseases.

Population studies in Northern Ireland (Cardwell et al. 2005), England (Goldacre 2017), Western Australia (Haynes et al. 2007) and Sweden (Crump et al. 2011) have reported a $17-43 \%$ increased risk of type 1 diabetes following preterm birth. The English and Western Australian studies (Haynes et al. 2007, Goldacre 2017), and a single-centre population cohort study from Israel (Paz Levy et al. 2017), also report an increased risk of type 1 diabetes following early term birth (37- to 38-weeks' gestation) when compared with full term births, consistent 
with the concept that gestational age reflects a spectrum of maturation that crosses the traditional boundary of preterm and term at 37-weeks' gestation (The American College of Obstetricians and Gynecologists 2013). In contrast, a population study from Norway (Stene et al. 2001) and a smaller study across Europe (Dahlquist et al. 1999) did not find an association between type 1 diabetes and gestational age. However, it is important to note that these two studies investigated childhood onset of type 1 diabetes and so would not detect an association between preterm birth and type 1 diabetes with onset beyond 15 years of age. A cross-sectional population study from Israel reported that the proportion of children with type 1 diabetes born at full term (37-42 weeks' gestation) was significantly less than the proportion of the population without type 1 diabetes born at full term $(83.8 \%$ versus $87.7 \%)$, but did not find a statistically significant increase in type 1 diabetes in those born preterm compared with those born at term (8.3\% vs $7.6 \%)$ (Adar et al. 2018).

Cohort studies also suggest that there is an association between preterm birth and type 2 diabetes (Lawlor et al. 2006, Kaijser et al. 2009, Kajantie et al. 2010, Pilgaard et al. 2010). Although the sample sizes in these studies are much smaller than for the studies of type 1 diabetes, the estimated pooled relative risk from a meta-analysis suggests a $50 \%$ increased risk (95\% CIs 32-72\%) (Li et al. 2014). Once again, the studies are not all consistent, with a cohort study from China (Xiao et al. 2008) not reporting an association between risk of type 2 diabetes and gestational age and the Helsinki birth cohort study finding an increased risk for type 2 diabetes following preterm birth below 35-weeks' gestation but a trend towards a decreased risk at 35- to 37-weeks' gestation (Kajantie et al. 2010). The different findings may reflect the different subjects included in these studies, with, for example, the Scandinavian cohort studies linking birth data with diagnosis of type 2 diabetes from hospital discharge data (Kaijser et al. 2009) or with a registry of medication for diabetes (Kajantie et al. 2010), thus potentially missing mild cases of diabetes, whereas the cohort study from Beijing (Xiao et al. 2008) included 2019/2085 survivors of 12,097 births between 1921 and 1954 in one hospital in Beijing, which is likely to select for healthier individuals. For the Aberdeen birth cohort study, birth data were linked with self-reported diagnosis of diabetes.

The epidemiological findings are supported by several, but not all (Willemsen et al. 2009), experimental studies investigating insulin sensitivity in children and young adults, which report decreased insulin sensitivity in those born preterm compared with term-born controls
(Hofman et al. 2004, Hovi et al. 2007, Rotteveel et al. 2008, Willemsen et al. 2008, Mathai et al. 2012). The associations between preterm birth and later insulin sensitivity are compounded by postnatal factors across the life-course, particularly environmental factors such as exercise and diet that impact upon body composition (Tinnion et al. 2014).

These associations of preterm birth with type 1 and 2 diabetes are independent of birthweight, with increasing birthweight associated with an increased risk of type 1 diabetes (Harder et al. 2009, Goldacre 2017) and both high and low birthweight associated with type 2 diabetes (Harder et al. 2007). Thus, the balance of evidence suggests that preterm birth is associated with increased incidences of both type 1 and 2 diabetes and that risk for diabetes is already present in childhood or early adulthood.

The global burden of diabetes is increasing, not only for type 2 diabetes (Chen et al. 2011), but also for type 1 diabetes, particularly in younger children (Patterson et al. 2009). Preterm births account for approximately $10 \%$ of all births and survival rates from very and extremely preterm birth are increasing. If the risk of diabetes following preterm birth is increased by $25-35 \%$ compared with those not born preterm, then prematurity potentially is contributing significantly to the global burden of diabetes.

\section{How might preterm birth be linked with later diabetes?}

Onset of type 2 diabetes is characterised by a functional pancreatic $\beta$-cell mass that is no longer able to compensate for the prevailing insulin resistance (Rhodes 2005). In contrast, in type 1 diabetes, loss of $\beta$-cell mass is a primary feature. As both types 1 and 2 diabetes are associated with preterm birth, it could be speculated that the mechanism may include a direct effect on the developing pancreas. Information on the developing human pancreas is understandably scarce, but available data indicate that most $\beta$-cell neogenesis occurs preterm with $\beta$-cell proliferation from pancreatic ductal cells occurring in both the fetus and neonate (Polak et al. 2000, Gregg et al. 2012). $\beta$-cell neogenesis after birth is thought to occur at very low rates $(\leq 0.5 \%)$ with apoptosis also at low rates $(\leq 1.5 \%)$ (Butler et al. 2007, Gregg et al. 2012). Thus, the baseline $\beta$-cell mass forming the population from which any later expansion, in response to metabolic demand or physiological states, such as pregnancy, is established early in life. It follows that a reduction in baseline $\beta$-cell mass is likely to impact upon a compensatory response 
to metabolic demand with limited ability for significant $\beta$-cell turnover in adulthood (Perl et al. 2010). However, there is no evidence on whether baseline $\beta$-cell mass prior to the onset of autoimmunity is a factor in the risk of developing type 1 diabetes.

In the fetal sheep (Fowden 1980, Aldoretta et al. 1998) and horse (Fowden et al. 1980, 1982, 2005), and also in atricial species such as the rat (Kervran et al. 1979, Kervran \& Randon 1980), there are maturational changes in pancreatic function in late gestation with increasing insulin secretion in response to glucose and arginine stimulation. These changes are associated with increasing endogenous cortisol concentrations in the prepartum period (Fowden et al. 2005), can be modified by exogenous stimuli such as maternal undernutrition (Oliver et al. 2001), multiple conception (Rumball et al. 2008, Green et al. 2011) and exogenous glucocorticoid administration (Valenzuela et al. 2017) and extend into postnatal life. It has also been reported that there is a wave of $\beta$-cell apoptosis in late gestation in the human (Tornehave \& Larsson 1997), which may represent a change from fetal $\beta$-cells to more mature $\beta$-cells in preparation for extra-uterine life. A similar wave of apoptosis has been described in the neonatal period in the rat (Scaglia et al. 1997, Hill \& Duvillie 2000), reflecting different timing of pancreatic development in relation to birth in this altricial species, which may be an important factor in experiments investigating the impact of preterm birth on development of the critical $\beta$-cell mass on which later capacity to respond to metabolic demand rests.

In considering how preterm birth might impact upon the developing $\beta$-cell, it is important to bear in mind that the effects might arise from maternal, fetal or pregnancy-related factors that led to the preterm birth; the impact of preterm birth itself on the metabolism, organ development and physiology of the fetus-neonate or from the impact of any care provided to the preterm neonate following birth (Fig. 1).

\section{Association between factors leading to preterm birth and later glucose intolerance}

Preterm birth is a syndrome with multiple preceding factors (Blencowe et al. 2013a), extending from genetic, environmental and through to iatrogenic - that is, where the medical providers make the decision to initiate

Factors related to preterm birth that may affect development of beta-cell mass

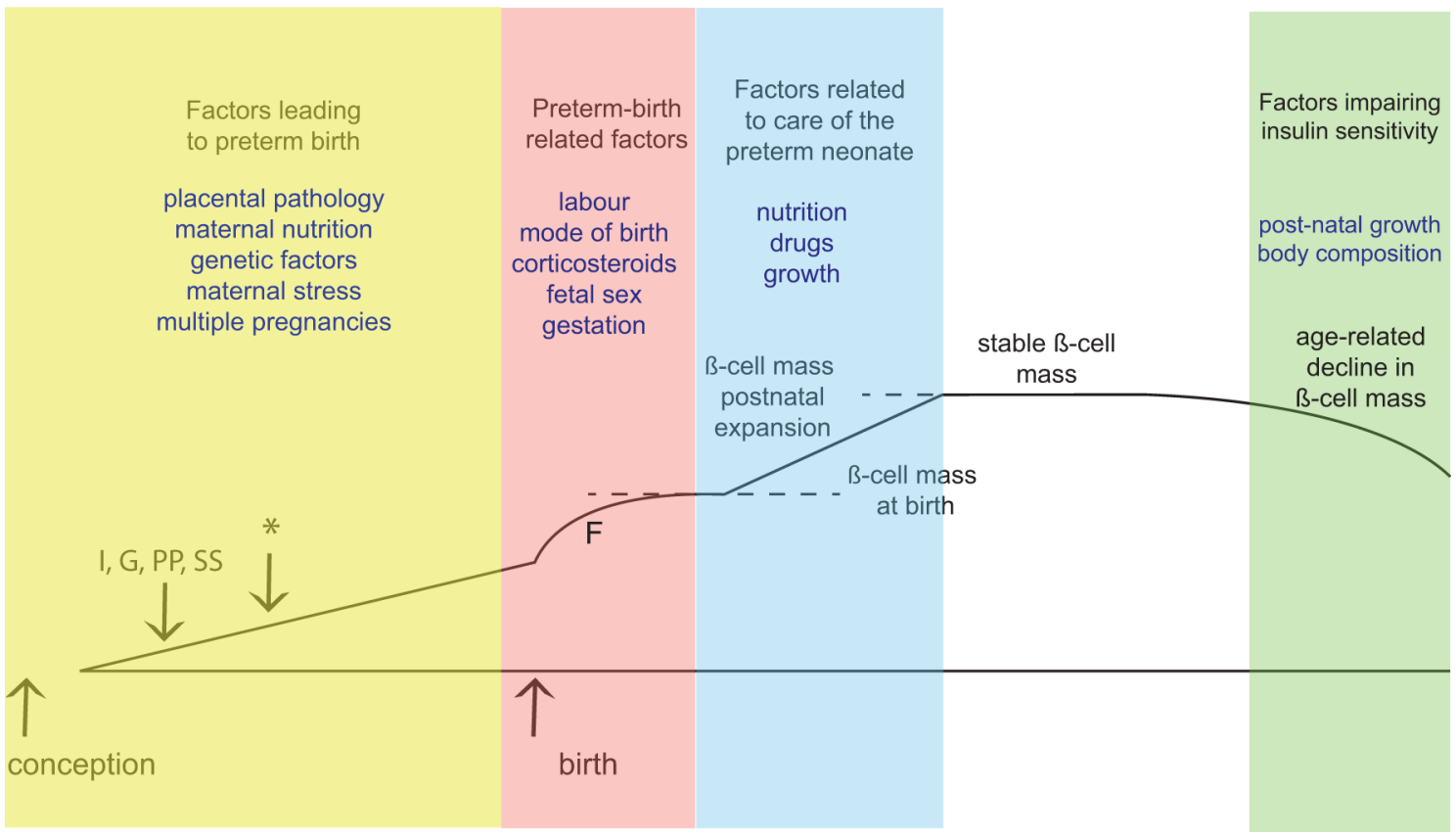

\section{Figure 1}

Schematic of development of beta-cell mass. Cells staining positive for insulin (I), glucagon (G), pancreatic polypeptide (PP) and somatostatin (SS) appear early in development, before the appearance of recognisable islets (*). Around the time of birth, if labour occurs there is a prepartum surge of fetal cortisol (F), which is associated with a cluster of maturational changes. Following birth, there is a period of postnatal expansion of the beta cells, resulting in a baseline beta-cell mass that is relatively stable thereafter. Factors throughout pregnancy (and from before conception), birth and the neonatal period may impact upon establishment of this baseline beta-cell mass. Factors operating later in life, such as obesity, may contribute to impaired insulin sensitivity. 
preterm delivery, usually for reasons related to maternal or fetal health. Genome-wide association studies have been relatively disappointing in identifying SNPs associated with spontaneous preterm birth, although a recent study identified four loci that were significantly associated with gestation length (Zhang et al. 2017), including Early B-cell Factor 1, which also is associated with increased blood glucose and diabetes (Singh et al. 2015). Newer approaches that integrate data on SNP interactions using spatial genomic connectivity (using chromosome conformational capture) with functional outcomes (Fadason et al. 2017) may lead to new insights into the association between gestation length and diabetes.

Maternal factors such as nutrition, multiple pregnancies and stress also are associated with preterm birth and with later risk for diabetes (Blencowe et al. 2013a). Experimental and human data suggest that the critical period for these factors is in the very early, periconceptional period. For example, poor maternal nutrition in early pregnancy is associated with preterm birth in studies in sheep (Bloomfield et al. 2003) and in humans (Rayco-Solon et al. 2005, Bloomfield 2011b) and experimental studies in sheep indicate that reduced gestation length and size in multiples also is determined in early pregnancy (Hancock et al. 2012). Similarly, maternal exposure to acute stress during pregnancy has been reported to increase preterm birth, with most studies reporting the greatest effects if the exposure is in the first trimester (Zhu et al. 2010, Class et al. 2011, Oyarzo et al. 2012, Torche \& Kleinhaus 2012).

In both human and sheep studies, offspring following maternal undernutrition (Todd et al. 2009, Roseboom et al. 2011, de Rooij et al. 2014), maternal stress (Entringer et al. 2008, Brunton et al. 2013) and twin pregnancy (Grunnet et al. 2007, Monrad et al. 2009, Poulsen et al. 2009, Donovan et al. 2017) are at increased risk of impaired glucose tolerance and diabetes in adulthood. It is likely that these effects are mediated through epigenetic modifications in the fetus (Bloomfield 2011a, Cao-Lei et al. 2017).

\section{Potential effect of being born preterm on later glucose intolerance}

Birth at any gestation is associated with substantial physiological and endocrinological changes that enable the newborn to adapt to extra-uterine life (Riviere et al. 2017). The fetus in all species studied demonstrates an endogenous glucocorticoid surge (Fowden et al. 1998) that, together with increasing production of thyroid hormones and increased peripheral conversion of thyroxine to T3, is responsible for maturation of many enzymes and organ systems prior to birth. Maturation of both cortisol and thyroid hormone secretion are related to gestational age and are blunted in the preterm infant (Ballard et al. 1998, Travers et al. 2018). The maturational role of glucocorticoids has been harnessed as a fetal treatment in women at risk of preterm birth, resulting in reduced mortality and morbidity in preterm neonates (Liggins \& Howie 1972), but the addition of thyroidreleasing hormone to this maternal treatment did not have any additional beneficial effect (Crowther et al. $2013 a$ ). Although studies in a variety of animal species have reported that antenatal glucocorticoids result in a metabolic profile in the offspring that indicates metabolic risk (Seckl \& Holmes 2007), the 30-year follow-up of the original antenatal glucocorticoid trial reported only a small ( 16\%), although statistically significant, increase in insulin concentration 30 minutes after a $75 \mathrm{~g}$ oral glucose tolerance test, with decreased glucose concentration at 120 minutes, in the offspring exposed to antenatal glucocorticoids compared with those exposed to placebo (Dalziel et al. 2005). It is not yet known whether this clinically insignificant finding at age 30 years could amplify into clinically relevant insulin resistance as the subjects age. However, in the whole cohort within this trial, both a lower gestational age and being born preterm were associated with an increased insulin area under the curve in the glucose tolerance test, suggesting an independent inverse relationship between gestation length and insulin resistance age 30 years (Dalziel et al. 2007). Given that administration of antenatal glucocorticoids to women at risk of preterm birth is considered standard of care in higher income countries (Antenatal Corticosteroid Clinical Practice Guidelines Panel 2015), the potential impact of this treatment on the fetal pancreas needs to be considered as part of the context of preterm birth.

Catecholamines also are released in the peripartum period and are important in maintaining free fatty acid and glucose concentrations, but also have been implicated in developmental adaptations in fetal $\beta$ cells (Boehmer et al. 2017). In addition, there are dramatic changes in arterial oxygen saturation, the requirement for thermogenesis and the cessation of a continuous supply of nutrition across the placenta. These endocrinological and physiological changes have been proposed to impact upon development of a variety of organs, with potential long-term consequences (Fowden et al. 1998). For example, preterm birth has been reported in animal studies to lead to life-long deficits in nephron endowment 
(Zohdi et al. 2012) and cardiomyocyte number (Bensley et al. 2010, 2018).

Preterm birth is a condition of altered immune function (Sharma et al. 2012) and most of the significant neonatal morbidities accompanying significantly preterm birth, such as bronchopulmonary dysplasia, necrotising enterocolitis, retinopathy of prematurity and white matter injury, are associated with a pro-inflammatory state (Dong et al. 2018). Infection is common in preterm babies, and more so in boys than in girls, and is implicated in the pathogenesis of these pro-inflammatory morbidities (O'Driscoll et al. 2017a,b, Dong et al. 2018). Furthermore, there is evidence of altered T-cell function in preterm birth with, for example, increased regulatory T cells, which may increase the risk of neonatal infection (Pagel et al. 2016). Immune function in preterm babies may also differ by sex (O'Driscoll et al. 2017a,b). A study in Denmark identified all children over a 3-year period diagnosed with type 1 diabetes before the age of 15 years and investigated early childhood factors associated with type 1 diabetes (Svensson et al. 2005). Neonatal infection in boys, but not girls, was associated with a five-fold increased risk of developing diabetes. Thus, the association between preterm birth and type 1 diabetes may be mediated through immune mechanisms rather than a direct effect on baseline $\beta$-cell mass, consistent with the autoimmune nature of this condition.

\section{Impact of neonatal care}

The preterm neonate may be exposed to a wide variety of interventions, particularly those born at earlier gestational ages. However, given that the association between preterm birth and later risk of diabetes appears to exist across the gestational age spectrum, and even into early term gestations as discussed earlier, it seems reasonable to consider interventions that apply to all preterm babies. The most ubiquitous is nutrition and its impact upon growth (Harding et al. 2017). Preterm babies are, as a population, born smaller than their gestational age-matched counterparts who remain in utero until term (Cooke 2007) and also are very likely to suffer postnatal faltering growth (Harding et al. 2017). Breastmilk alone may not be able to sustain recommended postnatal growth rates, so additional nutritional support is often provided (Harding et al. 2017). By the time preterm babies, even those born at late preterm gestations, reach term-corrected age, they have a different body composition from term-born babies, with increased \% body fat and an altered fat distribution (Uthaya et al. 2005, Gianni et al. 2009). After discharge, a period of accelerated or 'catch-up' growth is common in preterm infants. Postnatal 'catch-up' growth has been associated with increased metabolic risk in adolescence and adulthood (Rotteveel et al. 2008, Singhal et al. 2010, Belfort et al. 2013, Embleton et al. 2016). Some studies report this association even for accelerated growth in the first few weeks after birth, with preterm babies randomised to a nutrient-enriched diet having higher fasting concentrations of insulin in adolescence compared with controls (Singhal \& Lucas 2004). Other studies have not found an association between growth in the early postnatal period and later metabolic risk (Embleton et al. 2016). The association between childhood growth in infants born preterm and later metabolic risk is stronger than for growth in the neonatal period. For example, in a cohort study of 945 preterm infants, a one standard deviation increase in weight between term-corrected age and 4 months was associated with a $27 \%$ increased risk of overweight and obesity at age 8 years (Belfort et al. 2013). Insulin sensitivity at age 21 years also has been reported to be lower in preterm-born subjects who demonstrated greater height and weight standard deviation scores in childhood (Rotteveel et al. 2008). However, the optimal growth trajectory and nutritional management for preterm babies for later metabolic health is not yet clear (Ong et al. 2015).

\section{Experimental studies of preterm birth on the developing beta-cell and pancreas}

In human observational studies, it is very difficult to separate out the effect of preterm birth from the antenatal factors that led to preterm birth and which may also have impacted upon organ development, particularly when in approximately $50 \%$ of cases of spontaneous preterm birth, the antecedent factors are unknown (Blencowe et al. 2013a). On the other hand, it is challenging keeping preterm animals alive, even at moderate preterm gestations (De Matteo et al. 2010), although antenatal glucocorticoids improve survival just as in the human (Nguyen et al. 2017).

In the sheep, the timing of development of the pancreas, including of islets, is similar to the human (Bryden et al. 1972, Reddy et al. 1988a,b, Reddy \& Elliott 1988, Piper et al. 2004), whereas in the rodent, several aspects take place during postnatal rather than in fetal life (Cole et al. 2009, Green et al. 2010).

We recently have undertaken a series of studies in sheep aimed at separating out the effects of preterm 
birth, neonatal hyperglycaemia (a common metabolic complication of extremely preterm birth), nutritional supplementation, postnatal growth and exogenous glucocorticoid exposure on glucose-insulin metabolism.

\section{Effect of preterm birth in sheep on beta-cell development}

Singleton-bearing ewes had labour induced with dexamethasone, giving birth at 137-day gestation (term $=148$ days) (Bansal et al. $2015 b$ ).

Dexamethasone-induced preterm birth resulted in reduced $\beta$-cell mass by 4 weeks post-term, which persisted through to 12 months (young adulthood in sheep), with both absolute and relative $\beta$-cell mass reduced by $65 \%$ compared with term-born controls (Bansal et al. $2015 b$ ). The reduction in $\beta$-cell mass at 12 months of age was associated with a greater $\beta$-cell apoptosis: proliferation ratio and decreased mRNA levels of IGF2, SLC2A2, GLUCOKINASE, INSULIN, and impaired insulin secretory capacity in response to a hyperglycaemic clamp. Induction of 12 days of sustained hyperglycaemia in the immediate postnatal period (Alsweiler et al. 2013) did not have any additional impact on the physiological findings, although it did lead to increased $\beta$-cell apoptosis in young adulthood, an effect that was reversed by normalisation of neonatal euglycaemia with a concurrent insulin infusion (Bansal et al. 2015b). Subsequent studies comparing dexamethasone-induced preterm lambs with those not exposed to glucocorticoids but with preterm birth induced by epostane, an inhibitor of $3 \beta$-hydroxysteroid dehydrogenase, which reduces circulating progesterone concentrations, indicates that antenatal dexamethasone had a protective, rather than adverse, effect on the developing pancreas (Bansal et al. 2015a). These studies support the hypothesis that preterm birth itself has adverse effects on the development of the pancreas, affecting the critical baseline $\beta$-cell mass through to adulthood. The magnitude of reduction in $\beta$-cell mass and the indication of impaired insulin secretion in response to hyperglycaemia indicate that normal glucose homeostasis may become impaired as the animals age.

However, a subsequent experiment by others also investigated the effect of preterm birth, induced with epostane but with concurrent exposure of betamethasone, did not find any effect on $\beta$-cell mass or on adult insulin secretion, although baseline glucose concentrations were elevated in adult female sheep born preterm (De Matteo et al. 2017). It is not clear why these two studies found opposite effects, but there are significant differences

(c) 2018 Society for Endocrinology Published by Bioscientifica Ltd. Printed in Great Britain between the two studies, most notably the use of epostane as an induction agent in both preterm and term animals in the study by De Matteo compared with animals born spontaneously at term in the study by Bansal et al, raising the possibility of effects of epostane in the term-born animals that may obscure effects of preterm birth, the different glucocorticoid used and the different survival rate of preterm lambs through to adulthood (57\% in the study by De Matteo vs 90\% in our studies (Alsweiler 2010)), which may have led to more vulnerable lambs being lost from the follow-up studies of pancreatic function. Clinically, betamethasone is the more commonly used glucocorticoid in women at risk of preterm birth, although a randomised controlled trial comparing betamethasone with dexamethasone has been completed and is expected to be reported in 2018 (Crowther et al. 2013b).

\section{Effect of neonatal nutritional supplementation on the $\beta$-cell and pancreatic function}

We then went on to investigate the role of nutritional supplementation on pancreatic development and function in both term (Berry et al. 2016, Jaquiery et al. 2016) and preterm lambs (Berry et al. 2016). The milk supplement was designed to be analogous to a human milk fortifier used routinely in many neonatal intensive care units, providing similar percentage increases in all macronutrients but accounting for the different composition of ewe's milk. The milk supplement was given by oral gavage four times per day for 2 weeks and did not affect milk intake from the mother, measured by deuterium oxide dilution. Despite a net increase in nutritional intake, there were minimal effects on growth (Berry et al. 2016). However, there were sexually dimorphic effects on insulin secretion with effects apparent in juvenile, but not adult, females but in adult, but not juvenile males, and opposite effects in supplemented preterm and term animals. Supplemented preterm adult males had fasting insulin concentrations approximately twice those of unsupplemented preterm controls, whereas the opposite effect was found in term males (Berry et al. 2016). Similarly, supplemented preterm males had a greater insulin response to an intravenous glucose tolerance test in adulthood compared with unsupplemented preterm controls, whereas supplemented term males had a lesser response than unsupplemented term controls. Supplemented preterm females demonstrated increased insulin secretion compared with control preterm females during the steady state phase of a hyperglycaemic clamp, but only at 4 months of age; by 14 months (adulthood), 
there was no longer any significant difference. Once again, the converse effect was seen in supplemented term females (Berry et al. 2016).

In a separate cohort of term lambs, we demonstrated that supplementation with a ewe's milk fortifier for 2 weeks also had sexually dimorphic effects on mRNA expression of key pancreatic genes involved in development of the $\beta$-cell 4 months later (post-weaning) in a manner consistent with the physiological findings described earlier. In males, supplementation decreased mRNA levels of the key $\beta$-cell transcription factor $P D X 1$, the growth factor IGF2 and the beta-cell glucose transporter SLC2A2 compared with unsupplemented males, whereas in females, supplementation increased mRNA levels of INSULIN and the beta-cell glucose sensor GLUCOKINASE compared with unsupplemented females. In the case of PDX1, there were epigenetic modifications to the promoter region in supplemented animals, with decreased methylation in both sexes and altered histone methylation and acetylation in supplemented females only (Jaquiery et al. 2016), indicating that brief nutritional supplementation alters epigenetic marks in this key transcription factor that persist after cessation of supplementation and, indeed, beyond weaning, suggesting that these changes may be permanent.

\section{Conclusions}

These experiments in preterm lambs begin to unpick the different components of the environment that preterm babies are exposed to and how these may affect the developing pancreas. They demonstrate that preterm birth itself, at least in the presence of standard care with antenatal glucocorticoids, likely impacts upon the developing $\beta$-cell in a way that may reduce pancreatic capacity to secrete insulin in response to increased metabolic demand or when there is a further reduction in capacity as the animal ages. Similarly, in lambs there are effects of supplementation with a milk fortifier, analogous to human milk fortifier, which differ according to the sex of the lamb and that appear to operate, at least in part, through epigenetic mechanisms. Furthermore, these effects were independent of accelerated postnatal growth, raising the possibility that nutrition itself, irrespective of growth, may impact upon the developing beta-cell. If these findings should translate to the clinical setting, they suggest that urgent studies into whether nutrition for preterm girls and boys should be different are needed and also whether the emphasis that currently is placed on
https://doi.org/10.1530/JOE-18-0021 attempting to achieve intrauterine growth rates in babies born preterm is justified.

Further research clearly is needed. As survival of preterm babies improves, attention needs to focus more on the long-term outcomes, including both metabolic and neurodevelopmental outcomes. The possibility for intervention into the antecedent causes of preterm birth as a means of improving neonatal outcome is small; attention therefore needs to focus on the effects of preterm birth and management of the preterm neonate. The question of the role of antenatal glucocorticoids on the beta-cell still is not fully resolved and remains an important question as there is a move in some jurisdictions towards use of antenatal glucocorticoids prior to birth, particularly operative birth, at late preterm and early term gestations (Committee Opinion No. 713 2017). Nutrition is a fundamental component of care for all babies; yet, there is limited high-quality evidence to guide practice. The potential for nutritional practices to affect development of both the pancreas and later insulin sensitivity requires further investigation, including the possibility that nutritional requirements, macronutrient balance and long-term consequences of nutritional practices may be different in girls and boys.

\section{Declaration of interest}

The author declares that there is no conflict of interest that could be perceived as prejudicing the impartiality of this review.

\section{Funding}

This work did not receive any specific grant from any funding agency in the public, commercial, or not-for-profit sector.

\section{References}

Adar A, Shalitin S, Eyal O, Loewenthal N, Pinhas-Hamiel O, Levy M, Dally-Gottfried O, Landau Z, Zung A, Levy-Khademi F, et al. 2018 Prevalence of early and late prematurity is similar among pediatric type 1 diabetes patients and the general population. Diabetes and Metabolic Research Reviews e2996. (https://doi.org/10.1002/dmrr.2996)

Aldoretta PW, Carver TD \& Hay WW Jr 1998 Maturation of glucosestimulated insulin secretion in fetal sheep. Biology of the Neonate $\mathbf{7 3}$ 375-386. (https://doi.org/10.1159/000014000)

Alsweiler JM 2010 The effects and management of neonatal hyperglycaemia. PhD Thesis. University of Auckland, Australia.

Alsweiler JM, Harding JE \& Bloomfield FH 2013 Neonatal hyperglycaemia increases mortality and morbidity in preterm lambs. Neonatology 103 83-90. (https://doi.org/10.1159/000342240)

Antenatal Corticosteroid Clinical Practice Guidelines Panel 2015 Antenatal Corticosteroids Given to Women Prior to Birth to Improve Fetal, Infant, Child and Adult Health: Clinical Practice Guidelines. 
Auckland, Australia: Liggins Institute, University of Auckland. (available at: www.ligginstrials.org/ANC_CPG/)

Ballard PL, Ballard RA, Ning Y, Cnann A, Boardman C, Pinto-Martin J, Polk D, Phibbs RH, Davis DJ, Mannino FL, et al. 1998 Plasma thyroid hormones in premature infants: effect of gestational age and antenatal thyrotropin-releasing hormone treatment. TRH Collaborative Trial Participants. Pediatric Research 44 642-649. (https://doi.org/10.1203/00006450-199811000-00005)

Bansal A, Alsweiler JM, Phua HH, Connor KL, Dragunow M, de Matteo R, Harding JE \& Bloomfield FH 2015a Effects of non-steroid vs steroidinduced preterm birth in sheep on expression of genes involved in insulin secretion and hepatic insulin sensitivity. 9th World Congress on Developmental Origins of Health and Disease. Journal of the Developmental Origins of Health and Disease 6 S138-S139. (https://doi. org/10.1017/S2040174415007801)

Bansal A, Bloomfield FH, Connor KL, Dragunow M, Thorstensen EB, Oliver MH, Sloboda DM, Harding JE \& Alsweiler JM 2015b Glucocorticoid-induced preterm birth and neonatal hyperglycemia alter ovine beta-cell development. Endocrinology 156 3763-3776. (https://doi.org/10.1210/en.2015-1095)

Belfort MB, Gillman MW, Buka SL, Casey PH \& McCormick MC 2013 Preterm infant linear growth and adiposity gain: tradeoffs for later weight status and intelligence quotient. Journal of Pediatrics 163 1564.e1562-1569.e1562. (https://doi.org/10.1016/j. jpeds.2013.06.032)

Bensley JG, Stacy VK, De Matteo R, Harding R \& Black MJ 2010 Cardiac remodelling as a result of pre-term birth: implications for future cardiovascular disease. European Heart Journal 31 2058-2066. (https:// doi.org/10.1093/eurheartj/ehq104)

Bensley JG, Moore L, De Matteo R, Harding R \& Black MJ 2018 Impact of preterm birth on the developing myocardium of the neonate. Pediatric Research 83 880-888. (https://doi.org/10.1038/pr.2017.324)

Berry MJ, Jaquiery AL, Oliver MH, Harding JE \& Bloomfield FH 2016 Neonatal milk supplementation in lambs has persistent effects on growth and metabolic function that differ by sex and gestational age. British Journal of Nutrition 116 1912-1925. (https://doi.org/10.1017/ S0007114516004013)

Blencowe H, Cousens S, Oestergaard MZ, Chou D, Moller AB, Narwal R, Adler A, Vera Garcia C, Rohde S, Say L, et al. 2012 National, regional, and worldwide estimates of preterm birth rates in the year 2010 with time trends since 1990 for selected countries: a systematic analysis and implications. Lancet 379 2162-2172. (https://doi.org/10.1016/ S0140-6736(12)60820-4)

Blencowe H, Cousens S, Chou D, Oestergaard M, Say L, Moller AB, Kinney M, Lawn J \& Born Too Soon Preterm Birth Action Group $2013 a$ Born too soon: the global epidemiology of 15 million preterm births. Reproductive Health 10 (Supplement 1) S2. (https://doi. org/10.1186/1742-4755-10-S1-S2)

Blencowe H, Lee AC, Cousens S, Bahalim A, Narwal R, Zhong N, Chou D, Say L, Modi N, Katz J, et al. 2013b Preterm birth-associated neurodevelopmental impairment estimates at regional and global levels for 2010. Pediatric Research 74 (Supplement 1) 17-34. (https:// doi.org/10.1038/pr.2013.204)

Blencowe H, Vos T, Lee AC, Philips R, Lozano R, Alvarado MR, Cousens S \& Lawn JE 2013c Estimates of neonatal morbidities and disabilities at regional and global levels for 2010: introduction, methods overview, and relevant findings from the Global Burden of Disease study. Pediatric Research 74 (Supplement 1) 4-16. (https://doi.org/10.1038/ pr.2013.203)

Bloomfield FH 2011a Epigenetic modifications may play a role in the developmental consequences of early life events. Journal of Neurodevelopmental Disorders 3 348-355. (https://doi.org/10.1007/ s11689-011-9096-1)

Bloomfield FH $2011 b$ How is maternal nutrition related to preterm birth? Annual Review of Nutrition 31 235-261. (https://doi.org/10.1146/ annurev-nutr-072610-145141)
Bloomfield FH, Oliver MH, Hawkins P, Campbell M, Phillips DJ, Gluckman PD, Challis JR \& Harding JE 2003 A periconceptional nutritional origin for noninfectious preterm birth. Science $\mathbf{3 0 0} 606$. (https://doi.org/10.1126/science.1080803)

Boehmer BH, Limesand SW \& Rozance PJ 2017 The impact of IUGR on pancreatic islet development and $\beta$-cell function. Journal of Endocrinology 235 R63-R76. (https://doi.org/10.1530/JOE-17-0076)

Brunton PJ, Sullivan KM, Kerrigan D, Russell JA, Seckl JR \& Drake AJ 2013 Sex-specific effects of prenatal stress on glucose homoeostasis and peripheral metabolism in rats. Journal of Endocrinology 217 161-173. (https://doi.org/10.1530/JOE-12-0540)

Bryden MM, Evans HE \& Binns W 1972 Embryology of the sheep. II. The alimentary tract and associated glands. Journal of Morphology 138 187-206. (https://doi.org/10.1002/jmor.1051380205)

Butler PC, Meier JJ, Butler AE \& Bhushan A 2007 The replication of beta cells in normal physiology, in disease and for therapy. Nature Clinical Practice in Endocrinology and Metabolism 3 758-768. (https://doi. org/10.1038/ncpendmet0647)

Cao-Lei L, de Rooij SR, King S, Matthews SG, Metz GAS, Roseboom TJ \& Szyf M 2017 Prenatal stress and epigenetics. Neuroscience Biobehavioral Reviews [epub]. (https://doi.org/10.1016/j.neubiorev.2017.05.016)

Cardwell CR, Carson DJ \& Patterson CC 2005 Parental age at delivery, birth order, birth weight and gestational age are associated with the risk of childhood Type 1 diabetes: a UK regional retrospective cohort study. Diabetes Medicine 22 200-206. (https://doi.org/10.1111/j.14645491.2005.01369.x)

Chen L, Magliano DJ \& Zimmet PZ 2011 The worldwide epidemiology of type 2 diabetes mellitus - present and future perspectives. Nature Reviews Endocrinology 8 228-236. (https://doi.org/10.1038/ nrendo.2011.183)

Class QA, Lichtenstein P, Langstrom N \& D'Onofrio BM 2011 Timing of prenatal maternal exposure to severe life events and adverse pregnancy outcomes: a population study of 2.6 million pregnancies. Psychosomatic Medicine 73 234-241. (https://doi.org/10.1097/ PSY.0b013e31820a62ce)

Cole L, Anderson M, Antin PB \& Limesand SW 2009 One process for pancreatic $\beta$-cell coalescence into islets involves an epithelialmesenchymal transition. Journal of Endocrinology 203 19-31. (https:// doi.org/10.1677/JOE-09-0072)

Committee Opinion No. 7132017 Antenatal corticosteroid therapy for fetal maturation. Obstetrics and Gynecology 130 e102-e109.

Cooke RW 2007 Conventional birth weight standards obscure fetal growth restriction in preterm infants. Archives of Disease in Childhood. Fetal and Neonatal Edition 92 F189-F192. (https://doi.org/10.1136/ adc.2005.089698)

Crowther CA, Alfirevic Z, Han S \& Haslam RR 2013a Thyrotropinreleasing hormone added to corticosteroids for women at risk of preterm birth for preventing neonatal respiratory disease. Cochrane Database Systematic Reviews CD000019. (https://doi org/10.1002/14651858)

Crowther CA, Harding JE, Middleton PF, Andersen CC, Ashwood P, Robinson JS \& A*STEROID Study Group 2013b Australasian randomised trial to evaluate the role of maternal intramuscular dexamethasone versus betamethasone prior to preterm birth to increase survival free of childhood neurosensory disability (A*STEROID): study protocol. BMC Pregnancy Childbirth 13104. (https://doi.org/10.1186/1471-2393-13-104)

Crump C, Winkleby MA, Sundquist K \& Sundquist J 2011 Risk of diabetes among young adults born preterm in Sweden. Diabetes Care 34 1109-1113. (https://doi.org/10.2337/dc10-2108)

Dahlquist GG, Patterson C \& Soltesz G 1999 Perinatal risk factors for childhood type 1 diabetes in Europe. The EURODIAB Substudy 2 Study Group. Diabetes Care 22 1698-1702. (https://doi.org/10.2337/ diacare.22.10.1698)

Dalziel SR, Walker NK, Parag V, Mantell C, Rea HH, Rodgers A \& Harding JE 2005 Cardiovascular risk factors after antenatal exposure 
to betamethasone: 30-year follow-up of a randomised controlled trial. Lancet 365 1856-1862. (https://doi.org/10.1016/S01406736(05)66617-2)

Dalziel SR, Parag V, Rodgers A \& Harding JE 2007 Cardiovascular risk factors at age 30 following pre-term birth. International Journal of Epidemiology 36 907-915. (https://doi.org/10.1093/ije/dym067)

Davidoff MJ, Dias T, Damus K, Russell R, Bettegowda VR, Dolan S, Schwarz RH, Green NS \& Petrini J 2006 Changes in the gestational age distribution among U.S. singleton births: impact on rates of late preterm birth, 1992 to 2002. Seminars in Perinatology 30 8-15. (https:// doi.org/10.1053/j.semperi.2006.01.009)

De Matteo R, Blasch N, Stokes V, Davis P \& Harding R 2010 Induced preterm birth in sheep: a suitable model for studying the developmental effects of moderately preterm birth. Reproductive Sciences 17 724-733. (https://doi.org/10.1177/1933719110369182)

De Matteo R, Hodgson DJ, Bianco-Miotto T, Nguyen V, Owens JA, Harding R, Allison BJ, Polglase G, Black MJ \& Gatford KL 2017 Betamethasone-exposed preterm birth does not impair insulin action in adult sheep. Journal of Endocrinology 232 175-187. (https://doi. org/10.1530/JOE-16-0300)

de Rooij SR, Roseboom TJ \& Painter RC 2014 Famines in the last 100 years: implications for diabetes. Current Diabetes Reports 14536. (https://doi.org/10.1007/s11892-014-0536-7)

Dong Y, Speer CP \& Glaser K 2018 Beyond sepsis: staphylococcus epidermidis is an underestimated but significant contributor to neonatal morbidity. Virulence 9 621-633. (https://doi.org/10.1080/215 05594.2017.1419117)

Donovan EL, Buckels EJ, Hancock S, Smeitink D, Oliver MH, Bloomfield FH \& Jaquiery AL 2017 Twin conception in sheep leads to impaired insulin sensitivity and sexually dimorphic adipose tissue and skeletal muscle phenotypes in adulthood. Reproductive Sciences $\mathbf{2 4}$ 865-881. (https://doi.org/10.1177/1933719116670516)

Embleton ND, Korada M, Wood CL, Pearce MS, Swamy R \& Cheetham TD 2016 Catch-up growth and metabolic outcomes in adolescents born preterm. Archives of Disease in Childhood 101 1026-1031. (https://doi. org/10.1136/archdischild-2015-310190)

Entringer S, Wust S, Kumsta R, Layes IM, Nelson EL, Hellhammer DH \& Wadhwa PD 2008 Prenatal psychosocial stress exposure is associated with insulin resistance in young adults. American Journal of Obstetrics and Gynecology 199 498.e491-498.e497.

Fadason T, Ekblad C, Ingram JR, Schierding WS \& O'Sullivan JM 2017 Physical interactions and expression quantitative traits loci identify regulatory connections for obesity and type 2 diabetes associated SNPs. Frontiers in Genetics 8 150. (https://doi.org/10.3389/ fgene.2017.00150)

Fowden AL 1980 Effects of arginine and glucose on the release of insulin in the sheep fetus. Journal of Endocrinology 85 121-129. (https://doi. org/10.1677/joe.0.0850121)

Fowden AL, Barnes RJ, Comline RS \& Silver M 1980 Pancreatic betacell function in the fetal foal and mare. Journal of Endocrinology 87 293-301. (https://doi.org/10.1677/joe.0.0870293)

Fowden AL, Ellis L \& Rossdale PD 1982 Pancreatic beta cell function in the neonatal foal. Journal of Reproduction and Fertility Supplement 32 529-535.

Fowden AL, Li J \& Forhead AJ 1998 Glucocorticoids and the preparation for life after birth: are there long-term consequences of the life insurance? Proceedings of the Nutrition Society 57 113-122. (https://doi. org/10.1079/PNS19980017)

Fowden AL, Gardner DS, Ousey JC, Giussani DA \& Forhead AJ 2005 Maturation of pancreatic beta-cell function in the fetal horse during late gestation. Journal of Endocrinology 186 467-473. (https://doi. org/10.1677/joe.1.06176)

Gianni ML, Roggero P, Taroni F, Liotto N, Piemontese P \& Mosca F 2009 Adiposity in small for gestational age preterm infants assessed at term equivalent age. Archives of Disease in Childhood Fetal and Neonatal Edition 94 F368-F372. (https://doi.org/10.1136/adc.2008.153163)
Goldacre RR 2017 Associations between birthweight, gestational age at birth and subsequent type 1 diabetes in children under 12: a retrospective cohort study in England, 1998-2012. Diabetologia 61 616-625. (https://doi.org/10.1007/s00125-017-4493-y)

Green AS, Rozance PJ \& Limesand SW 2010 Consequences of a compromised intrauterine environment on islet function. Journal of Endocrinology 205 211-224. (https://doi.org/10.1677/ JOE-09-0399)

Green AS, Macko AR, Rozance PJ, Yates DT, Chen X, Hay WW Jr \& Limesand SW 2011 Characterization of glucose-insulin responsiveness and impact of fetal number and sex difference on insulin response in the sheep fetus. American Journal of Physiology: Endocrinology and Metabolism 300 E817-E823. (https://doi.org/10.1152/ ajpendo.00572.2010)

Gregg BE, Moore PC, Demozay D, Hall BA, Li M, Husain A, Wright AJ, Atkinson MA \& Rhodes CJ 2012 Formation of a human beta-cell population within pancreatic islets is set early in life. Journal of Clinical Endocrinology and Metabolism 97 3197-3206. (https://doi. org/10.1210/jc.2012-1206)

Grunnet L, Vielwerth S, Vaag A \& Poulsen P 2007 Birth weight is nongenetically associated with glucose intolerance in elderly twins, independent of adult obesity. Journal of Internal Medicine 262 96-103. (https://doi.org/10.1111/j.1365-2796.2007.01793.x)

Hancock SN, Oliver MH, McLean C, Jaquiery AL \& Bloomfield FH 2012 Size at birth and adult fat mass in twin sheep are determined in early gestation. Journal of Physiology 590 1273-1285. (https://doi. org/10.1113/jphysiol.2011.220699)

Harder T, Rodekamp E, Schellong K, Dudenhausen JW \& Plagemann A 2007 Birth weight and subsequent risk of type 2 diabetes: a metaanalysis. American Journal of Epidemiology 165 849-857. (https://doi. org/10.1093/aje/kwk071)

Harder T, Roepke K, Diller N, Stechling Y, Dudenhausen JW \& Plagemann A 2009 Birth weight, early weight gain, and subsequent risk of type 1 diabetes: systematic review and meta-analysis. American Journal of Epidemiology 169 1428-1436. (https://doi.org/10.1093/aje/ kwp065)

Harding JE, Cormack BE, Alexander T, Alsweiler JM \& Bloomfield FH 2017 Advances in nutrition of the newborn infant. Lancet 389 1660-1668. (https://doi.org/10.1016/S0140-6736(17)30552-4)

Haynes A, Bower C, Bulsara MK, Finn J, Jones TW \& Davis EA 2007 Perinatal risk factors for childhood type 1 diabetes in Western Australia - a population-based study (1980-2002). Diabetes Medicine 24 564-570. (https://doi.org/10.1111/j.1464-5491.2007.02149.x)

Hill DJ \& Duvillie B 2000 Pancreatic development and adult diabetes. Pediatric Research 48 269-274. (https://doi.org/10.1203/00006450200009000-00002)

Hofman PL, Regan F, Jackson WE, Jefferies C, Knight DB, Robinson EM \& Cutfield WS 2004 Premature birth and later insulin resistance [erratum appears in N Engl J Med. 2004 Dec 30;351(27):2888]. New England Journal of Medicine 351 2179-2186. (https://doi.org/10.1056/ NEJMoa042275)

Hovi P, Andersson S, Eriksson JG, Jarvenpaa AL, Strang-Karlsson S, Makitie O \& Kajantie E 2007 Glucose regulation in young adults with very low birth weight. New England Journal of Medicine $\mathbf{3 5 6}$ 2053-2063. (https://doi.org/10.1056/NEJMoa067187)

Jaquiery AL, Park SS, Phua HH, Berry MJ, Meijler D, Harding JE, Oliver MH \& Bloomfield FH 2016 Brief neonatal nutritional supplementation has sex-specific effects on glucose tolerance and insulin regulating genes in juvenile lambs. Pediatric Research $\mathbf{8 0}$ 861-869. (https://doi.org/10.1038/pr.2016.168)

Kaijser M, Bonamy AK, Akre O, Cnattingius S, Granath F, Norman M \& Ekbom A 2009 Perinatal risk factors for diabetes in later life. Diabetes 58 523-526. (https://doi.org/10.2337/db08-0558)

Kajantie E, Osmond C, Barker DJ \& Eriksson JG 2010 Preterm birth - a risk factor for type 2 diabetes? The Helsinki birth cohort study. Diabetes Care 33 2623-2625. (https://doi.org/10.2337/dc10-0912) http://joe.endocrinology-journals.org

https://doi.org/10.1530/JOE-18-0021
() 2018 Society for Endocrinology Published by Bioscientifica Ltd. Printed in Great Britain 
Kervran A \& Randon J 1980 Development of insulin release by fetal rat pancreas in vitro: effects of glucose, amino acids, and theophylline. Diabetes 29 673-678. (https://doi.org/10.2337/diab.29.9.673)

Kervran A, Randon J \& Girard JR 1979 Dynamics of glucose-induced plasma insulin increase in the rat fetus at different stages of gestation. Biology of the Neonate 35 242-248. (https://doi. org/10.1159/000241180)

Lawlor DA, Davey Smith G, Clark H \& Leon DA 2006 The associations of birthweight, gestational age and childhood BMI with type 2 diabetes: findings from the Aberdeen Children of the 1950s cohort. Diabetologia 49 2614-2617. (https://doi.org/10.1007/s00125-006-0408-z)

Li S, Zhang M, Tian H, Liu Z, Yin X \& Xi B 2014 Preterm birth and risk of type 1 and type 2 diabetes: systematic review and meta-analysis. Obesity Reviews 15 804-811. (https://doi.org/10.1111/obr.12214)

Liggins GC \& Howie RN 1972 A controlled trial of antepartum glucocorticoid treatment for prevention of the respiratory distress syndrome in premature infants. Pediatrics 50 515-525.

Mathai S, Cutfield WS, Derraik JG, Dalziel SR, Harding JE, Robinson E, Biggs J, Jefferies C \& Hofman PL 2012 Insulin sensitivity and betacell function in adults born preterm and their children. Diabetes $\mathbf{6 1}$ 2479-2483. (https://doi.org/10.2337/db11-1672)

Monrad RN, Grunnet LG, Rasmussen EL, Malis C, Vaag A \& Poulsen P 2009 Age-dependent nongenetic influences of birth weight and adult body fat on insulin sensitivity in twins. Journal of Clinical Endocrinology and Metabolism 94 2394-2399. (https://doi.org/10.1210/ jc.2008-1858)

Nguyen VB, De Matteo R, Harding R, Stefanidis A, Polglase GR \& Black MJ 2017 Experimentally induced preterm birth in sheep following a clinical course of antenatal betamethasone: effects on growth and long-term survival. Reproductive Sciences 24 1203-1213. (https://doi. org/10.1177/1933719116681514)

O’Driscoll DN, De Santi C, McKiernan PJ, McEneaney V, Molloy EJ \& Greene CM 2017a Expression of X-linked Toll-like receptor 4 signaling genes in female vs. male neonates. Pediatric Research $\mathbf{8 1}$ 831-837. (https://doi.org/10.1038/pr.2017.2)

O’Driscoll DN, Greene CM \& Molloy EJ $2017 b$ Immune function? A missing link in the gender disparity in preterm neonatal outcomes. Expert Reviews in Clinical Immunology 13 1061-1071. (https://doi.org/1 0.1080/1744666X.2017.1386555)

Oliver MH, Hawkins P, Breier BH, Van Zijl PL, Sargison SA \& Harding JE 2001 Maternal undernutrition during the periconceptual period increases plasma taurine levels and insulin response to glucose but not arginine in the late gestational fetal sheep. Endocrinology $\mathbf{1 4 2}$ 4576-4579. (https://doi.org/10.1210/endo.142.10.8529)

Ong KK, Kennedy K, Castaneda-Gutierrez E, Forsyth S, Godfrey KM, Koletzko B, Latulippe ME, Ozanne SE, Rueda R, Schoemaker MH, et al. 2015 Postnatal growth in preterm infants and later health outcomes: a systematic review. Acta Paediatrica 104 974-986. (https://doi. org/10.1111/apa.13128)

Oyarzo C, Bertoglia P, Avendano R, Bacigalupo F, Escudero A, Acurio J \& Escudero C 2012 Adverse perinatal outcomes after the February 27th 2010 Chilean earthquake. Journal of Maternal-Fetal and Neonatal Medicine 25 1868-1873. (https://doi.org/10.3109/14767058.2012.678437)

Polak M, Bouchareb-Banaei L, Scharfmann R \& Czernichow P 2000 Early pattern of differentiation in the human pancreas. Diabetes 49 225-232. (https://doi.org/10.2337/diabetes.49.2.225)

Pagel J, Hartz A, Figge J, Gille C, Eschweiler S, Petersen K, Schreiter L, Hammer J, Karsten CM, Friedrich D, et al. 2016 Regulatory T cell frequencies are increased in preterm infants with clinical early-onset sepsis. Clinical and Experimental Immunology 185 219-227. (https:// doi.org/10.1111/cei.12810)

Patterson CC, Dahlquist GG, Gyurus E, Green A, Soltesz G \& EURODIAB Study Group 2009 Incidence trends for childhood type 1 diabetes in Europe during 1989-2003 and predicted new cases 2005-20: a multicentre prospective registration study. Lancet 373 2027-2033. (https://doi.org/10.1016/S0140-6736(09)60568-7)
Paz Levy D, Sheiner E, Wainstock T, Sergienko R, Landau D \& Walfisch A 2017 Evidence that children born at early term (37-38 6/7 weeks) are at increased risk for diabetes and obesity-related disorders. American Journal of Obstetrics and Gynecology 217 588.e1-588.e11. (https://doi. org/10.1016/j.ajog.2017.07.015)

Perl S, Kushner JA, Buchholz BA, Meeker AK, Stein GM, Hsieh M, Kirby M, Pechhold S, Liu EH, Harlan DM, et al. 2010 Significant human beta-cell turnover is limited to the first three decades of life as determined by in vivo thymidine analog incorporation and radiocarbon dating. Journal of Clinical Endocrinology and Metabolism 95 E234-E239. (https://doi.org/10.1210/jc.2010-0932)

Pilgaard K, Faerch K, Carstensen B, Poulsen P, Pisinger C, Pedersen O, Witte DR, Hansen T, Jorgensen T \& Vaag A 2010 Low birthweight and premature birth are both associated with type 2 diabetes in a random sample of middle-aged Danes. Diabetologia 53 2526-2530. (https:// doi.org/10.1007/s00125-010-1917-3)

Piper K, Brickwood S, Turnpenny LW, Cameron IT, Ball SG, Wilson DI \& Hanley NA 2004 Beta cell differentiation during early human pancreas development. Journal of Endocrinology 181 11-23. (https:// doi.org/10.1677/joe.0.1810011)

Poulsen P, Grunnet LG, Pilgaard K, Storgaard H, Alibegovic A, Sonne MP, Carstensen B, Beck-Nielsen H \& Vaag A 2009 Increased risk of type 2 diabetes in elderly twins. Diabetes 58 1350-1355. (https://doi. org/10.2337/db08-1714)

Rayco-Solon P, Fulford AJ \& Prentice AM 2005 Maternal preconceptional weight and gestational length. American Journal of Obstetrics and Gynecology 192 1133-1136. (https://doi.org/10.1016/j. ajog.2004.10.636)

Reddy S \& Elliott RB 1988 Ontogenic development of peptide hormones in the mammalian fetal pancreas. Experientia 44 1-9. (https://doi. org/10.1007/BF01960221)

Reddy S, Bibby NJ \& Elliott RB 1988a An immunofluorescent study of insulin-, glucagon-, pancreatic polypeptide- and somatostatincontaining cells in the early ovine fetal pancreas. Quarterly Journal of Experimental Physiology 73 225-232. (https://doi.org/10.1113/ expphysiol.1988.sp003135)

Reddy S, Bibby NJ \& Elliott RB $1988 b$ Ontogeny of islet cell antibodies, insulin autoantibodies and insulitis in the non-obese diabetic mouse. Diabetologia 31 322-328.

Rhodes CJ 2005 Type 2 diabetes-a matter of beta-cell life and death? Science 307 380-384. (https://doi.org/10.1126/science.1104345)

Riviere D, McKinlay CJD \& Bloomfield FH 2017 Adaptation for life after birth: a review of neonatal physiology. Anaesthesia and Intensive Care Medicine 18 59-68. (https://doi.org/10.1016/j. mpaic.2016.11.008)

Roseboom TJ, Painter RC, van Abeelen AF, Veenendaal MV \& de Rooij SR 2011 Hungry in the womb: what are the consequences? Lessons from the Dutch famine. Maturitas 70 141-145. (https://doi.org/10.1016/j. maturitas.2011.06.017)

Rotteveel J, van Weissenbruch MM, Twisk JW \& Delemarre-Van de Waal HA 2008 Infant and childhood growth patterns, insulin sensitivity, and blood pressure in prematurely born young adults. Pediatrics 122 313-321. (https://doi.org/10.1542/peds.2007-2012)

Rumball CW, Harding JE, Oliver MH \& Bloomfield FH 2008 Effects of twin pregnancy and periconceptional undernutrition on maternal metabolism, fetal growth and glucose-insulin axis function in ovine pregnancy. Journal of Physiology 586 1399-1411. (https://doi. org/10.1113/jphysiol.2007.144071)

Scaglia L, Cahill CJ, Finegood DT \& Bonner-Weir S 1997 Apoptosis participates in the remodeling of the endocrine pancreas in the neonatal rat. Endocrinology 138 1736-1741. (https://doi.org/10.1210/ endo.138.4.5069)

Seckl JR \& Holmes MC 2007 Mechanisms of disease: glucocorticoids, their placental metabolism and fetal 'programming' of adult pathophysiology. Nature Clinical Practice in Endocrinology and Metabolism 3 479-488. (https://doi.org/10.1038/ncpendmet0515) 
Sharma AA, Jen R, Butler A \& Lavoie PM 2012 The developing human preterm neonatal immune system: a case for more research in this area. Clinical Immunology 145 61-68. (https://doi.org/10.1016/j. clim.2012.08.006)

Singh A, Babyak MA, Nolan DK, Brummett BH, Jiang R, Siegler IC, Kraus WE, Shah SH, Williams RB \& Hauser ER 2015 Gene by stress genome-wide interaction analysis and path analysis identify EBF1 as a cardiovascular and metabolic risk gene. European Journal of Human Genetics 23 854-862. (https://doi.org/10.1038/ ejhg.2014.189)

Singhal A \& Lucas A 2004 Early origins of cardiovascular disease: is there a unifying hypothesis? Lancet 363 1642-1645. (https://doi. org/10.1016/S0140-6736(04)16210-7)

Singhal A, Kennedy K, Lanigan J, Fewtrell M, Cole TJ, Stephenson T, Elias-Jones A, Weaver LT, Ibhanesebhor S, MacDonald PD, et al. 2010 Nutrition in infancy and long-term risk of obesity: evidence from 2 randomized controlled trials. American Journal of Clinical Nutrition 92 1133-1144. (https://doi.org/10.3945/ajcn.2010.29302)

Stene LC, Magnus P, Lie RT, Sovik O, Joner G \& Norwegian childhood Diabetes Study G 2001 Birth weight and childhood onset type 1 diabetes: population based cohort study. British Medical Journal 322 889-892. (https://doi.org/10.1136/bmj.322.7291.889)

Svensson J, Carstensen B, Mortensen HB, Borch-Johnsen K \& Danish Study Group of Childhood D 2005 Early childhood risk factors associated with type 1 diabetes - is gender important? European Journal of Epidemiology 20 429-434. (https://doi.org/10.1007/s10654005-0878-1)

The American College of Obstetricians and Gynecologists 2013 Definition of term pregnancy. Committee opinion number 579. Obstetrics and Gynecology 122 1139-1140. (https://doi.org/10.1097/01. AOG.0000437385.88715.4a)

Tinnion R, Gillone J, Cheetham T \& Embleton N 2014 Preterm birth and subsequent insulin sensitivity: a systematic review. Archives of Disease in Childhood 99 362-368. (https://doi.org/10.1136/ archdischild-2013-304615)

Todd SE, Oliver MH, Jaquiery AL, Bloomfield FH \& Harding JE 2009 Periconceptional undernutrition of ewes impairs glucose tolerance in their adult offspring. Pediatric Research 65 409-413. (https://doi. org/10.1203/PDR.0b013e3181975efa)

Torche F \& Kleinhaus K 2012 Prenatal stress, gestational age and secondary sex ratio: the sex-specific effects of exposure to a natural disaster in early pregnancy. Human Reproduction 27 558-567. (https:// doi.org/10.1093/humrep/der390)

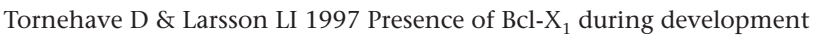
of the human fetal and rat neonatal endocrine pancreas: correlation to programmed cell death. Experimental and Clinical Endocrinology and Diabetes 105 A27-A28.

Travers S, Martinerie L, Boileau P, Lombes M \& Pussard E 2018 Alterations of adrenal steroidomic profiles in preterm infants at birth. Archives of Disease in Childhood Fetal and Neonatal Edition 103 F143-F151. (https://doi.org/10.1136/archdischild-2016-312457)

Uthaya S, Thomas EL, Hamilton G, Dore CJ, Bell J \& Modi N 2005 Altered adiposity after extremely preterm birth. Pediatric Research 57 211-215. (https://doi.org/10.1203/01.PDR.0000148284.58934.1C)

Valenzuela OA, Jellyman JK, Allen VL, Holdstock NB \& Fowden AL 2017 Effects of maternal dexamethasone treatment on pancreatic beta cell function in the pregnant mare and post natal foal. Equine Veterinary Journal 49 99-106. (https://doi.org/10.1111/evj.12560)

Willemsen RH, de Kort SW, van der Kaay DC \& Hokken-Koelega AC 2008 Independent effects of prematurity on metabolic and cardiovascular risk factors in short small-for-gestational-age children. Journal of Clinical Endocrinology and Metabolism 93 452-458. (https://doi. org/10.1210/jc.2007-1913)

Willemsen RH, Leunissen RW, Stijnen T \& Hokken-Koelega AC 2009 Prematurity is not associated with reduced insulin sensitivity in adulthood. Journal of Clinical Endocrinology and Metabolism 94 1695-1700. (https://doi.org/10.1210/jc.2008-1769)

Xiao X, Zhang ZX, Cohen HJ, Wang H, Li W, Wang T, Xu T, Liu A, Gai MY, Ying S, et al. 2008 Evidence of a relationship between infant birth weight and later diabetes and impaired glucose regulation in a Chinese population. Diabetes Care 31 483-487. (https://doi. org/10.2337/dc07-1130)

Zhang G, Feenstra B, Bacelis J, Liu X, Muglia LM, Juodakis J, Miller DE, Litterman N, Jiang PP, Russell L, et al. 2017 Genetic associations with gestational duration and spontaneous preterm birth. New England Journal of Medicine 377 1156-1167. (https://doi.org/10.1056/ NEJMoa1612665)

Zhu P, Tao F, Hao J, Sun Y \& Jiang X 2010 Prenatal life events stress: implications for preterm birth and infant birthweight. American Journal of Obstetrics and Gynecology 203 34.e1-8. (https://doi. org/10.1016/j.ajog.2010.02.023)

Zohdi V, Sutherland MR, Lim K, Gubhaju L, Zimanyi MA \& Black MJ 2012 Low birth weight due to intrauterine growth restriction and/ or preterm birth: effects on nephron number and long-term renal health. International Journal of Nephrology 2012 136942. (https://doi. org/10.1155/2012/136942)

Received in final form 31 May 2018

Accepted 12 June 2018

Accepted Preprint published online 12 June 2018
() 2018 Society for Endocrinology Published by Bioscientifica Ltd. Printed in Great Britain 